\title{
The Histomorphological Changes in the Proximal Tubules of Metanephros of Developing Kidney of Chick Embryo Induced by Electromagnetic Radiations from Conventional and Advanced Mobile Phones
}

Sabah Rehman ${ }^{1 *}$, Shadab Ahmed Butt ${ }^{1}$, Naureen Waseem ${ }^{2}$ and Maria Yousaf ${ }^{3}$

${ }^{1}$ Army Medical College, Rawalpindi, National University of Science and Technology, Islamabad

${ }^{2}$ Al Nafees Medical College, ISRA University, Islamabad

${ }^{3}$ Rehman medical college, peshawar

\begin{abstract}
Objective: The study was conducted to observe the histomorphogical effects of radiations from conventional and advanced mobile phone, on the developing kidney of chick embryo.

Study Design: Randomized Control Trial Duration of Study conducted at Army Medical College, NUST, Rawalpindi, 3months from May 2012 till July 2012.

Material and Methods: Fifty fertilized eggs of Fayoumi breed were selected and divided into five groups. Group I being control. Two groups II and IV were exposed to conventional mobile phone radiations and two groups III and V were exposed to advanced mobile phone radiations, for 15 and 30 minutes respectively.

Results: Statistically significant change in the tubular diameters was observed after advanced cellular radiations whereas conventional cellular radiations decreased the epithelial height significantly.

Conclusion: The changes induced by electromagnetic radiations from the advanced mobile phones affected the tubular diameters more by decreasing them while conventional decreased the epithelial height of the proximal tubule cells.
\end{abstract}

Keywords: Metanephros; Advanced mobile phone; Conventional mobile phone; Chick embryo

\section{Introduction}

Electromagnetic radiation is a form of energy emitted and absorbed by charged particles, exhibits wave-like behavior as it travels through space. EMR has both electric and magnetic field components, which stand in a fixed ratio of intensity to each other, and which oscillate in phase perpendicular to each other and perpendicular to the direction of energy and wave propagation. Mobile phone is a device that can make and receive telephone calls over a radiolink, by connecting to a cellular network. According to stroud district council, it is a two way radio. Voice is converted into radio waves by cell phone. The mobile phones that can be used only for the purpose of voice calls and messaging are the conventional ones. The electromagnetic radiation emitted by such mobile phone is in GSM frequency range of $850-1900 \mathrm{MHz}$, when used for phone calls and messaging [1]. Advanced mobile phones are the modern cell phones that are not used only for voice and message communication but also have additional features of Wi-Fi/WLAN technology, GPRS and Bluetooth.

\section{Material and Methods}

The study was carried out in Anatomy Department, Army Medical College Rawalpindi, in collaboration with Poultry Research Institute, Rawalpindi (Table 1). The eggs were divided into five groups, with 10 eggs in each group, by non-probability convenient sampling technique and above table shows the exposure of the groups to the radiations from the two type of cellular phones. The still-air incubator was used in the experiment with the temperature of $37^{\circ} \mathrm{C}$ and humidity range of $50-60 \%$ [2]. The incubator was 24 inch (length) $\times 24$ inch (width) $\times 12.5$ inch (height), with 100 eggs capacity. Four 100 watt bulbs were set inside for heat and thermostat was set at $37^{\circ} \mathrm{C}$. The temperature monitoring was carried out by mercury thermometer. The humidity was maintained by filling the plastic pans with water and it's monitoring done by hygrometer. The eggs were marked with ' $\mathrm{X}$ ' on one side and ' $\mathrm{O}$ ' on the other side with lead pencil and turned $180^{\circ}$ twice a day manually, for 15 days. The eggs were candled on 7th day by locally made candler and dead eggs were removed from the incubator. After the completion of exposure the chick embryos were decapitated and dissected for kidneys and tissue fixation,

\begin{tabular}{|c|c|}
\hline Groups & Exposure to The EMR \\
\hline Group I & Sham exposed \\
\hline $\begin{array}{c}\text { Group II (conventional mobile phone } \\
\text { radiations) }\end{array}$ & $\begin{array}{c}\text { Exposed to GSM (23 missed calls) } \\
\text { radiations for 15 minutes, daily for 15 } \\
\text { days }\end{array}$ \\
\hline $\begin{array}{c}\text { Group II (advanced mobile phone } \\
\text { radiations) }\end{array}$ & $\begin{array}{c}\text { Exposed to GSM (23 missed calls) and } \\
\text { Wi-Fi radiations by downloading files } \\
\text { for 15 minutes, daily for 15 days }\end{array}$ \\
\hline $\begin{array}{c}\text { Group IV (conventional mobile phone } \\
\text { radiations) }\end{array}$ & $\begin{array}{c}\text { Exposed to GSM radiations (45 missed } \\
\text { calls) for 30 minutes, daily for 15 days }\end{array}$ \\
\hline Group V (advanced mobile phone \\
radiations) & $\begin{array}{c}\text { Exposed to GSM (45 missed calls) and } \\
\text { Wi-Fi radiations by downloading files } \\
\text { for 30 minutes, daily for 15 days }\end{array}$ \\
\hline
\end{tabular}

Table 1: Fifty fertilized eggs of Fayoumi breed were used for the experiment.

*Corresponding author: Sabah Rehman, Anatomy Department (Instructor) Army Medical College, Rawalpindi, National University of Science and Technology Hno 118, Westridge-I, Peshawar Road Rawalpindi, Pakistan, Tel: 0320-9942678 E-mail: sabahrehman@live.com

Received March 28, 2015; Accepted May 30, 2015; Published June 06, 2015

Citation: Rehman S, Butt SA, Waseem N, Yousaf M (2015) The Histomorpholigical Changes in the Proximal Tubules of Metanephros of Developing Kidney of Chick Embryo Induced by Electromagnetic Radiations from Conventional and Advanced Mobile. Biol Med (Aligarh) 7: 237 doi: 10.4172/0974-8369.1000237

Copyright: (c) 2015 Rehman S, et al. This is an open-access article distributed under the terms of the Creative Commons Attribution License, which permits unrestricted use, distribution, and reproduction in any medium, provided the original author and source are credited. 
Citation: Rehman S, Butt SA, Waseem N, Yousaf M (2015) The Histomorpholigical Changes in the Proximal Tubules of Metanephros of Developing Kidney of Chick Embryo Induced by Electromagnetic Radiations from Conventional and Advanced Mobile. Biol Med (Aligarh) 7: 237 doi: 10.4172/0974-8369.1000237

Page 2 of 3
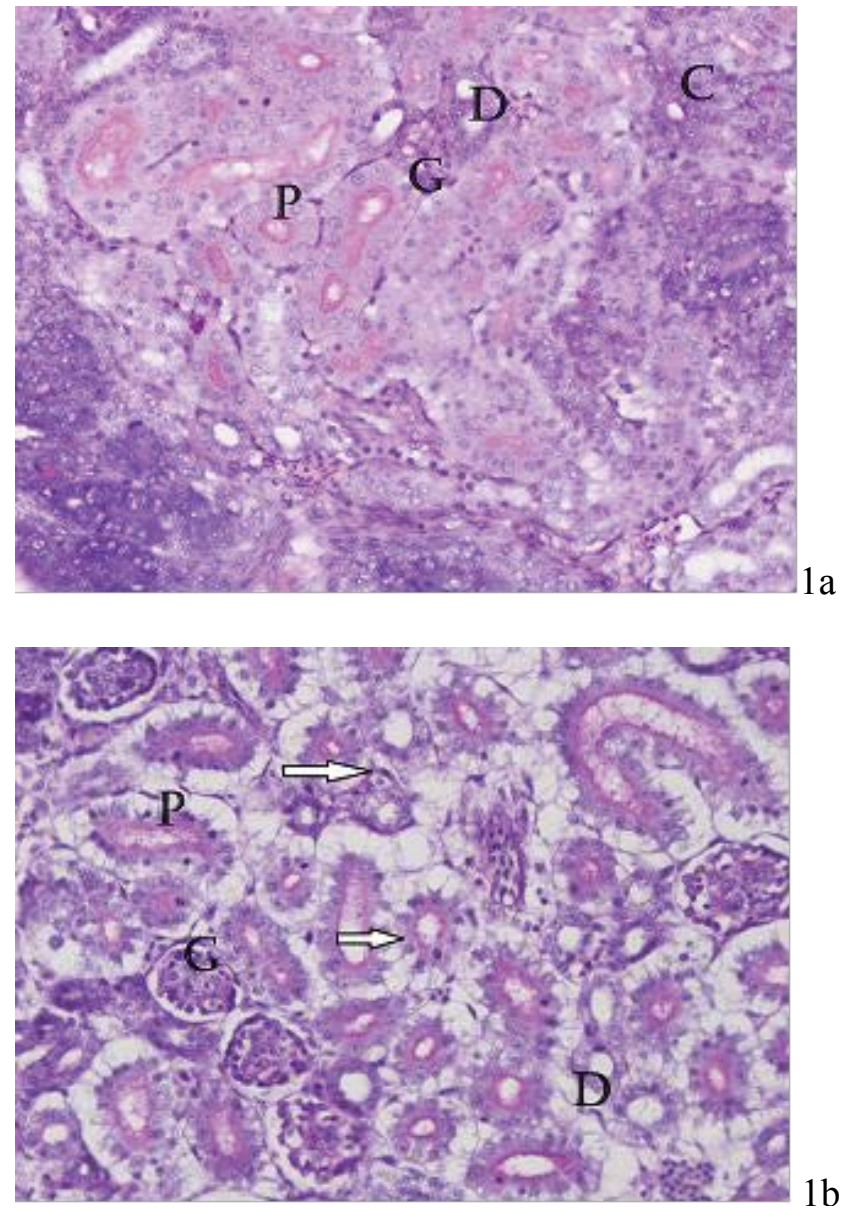

Figure 1: (a) Metanephros (PAS, Approx. X 2000) in the control group, P; proximal tubules withmagenta staining of brush border, $D$; distal tubules with noapicalstaining and $C$; collecting tubules with apices slightly PAS positive, G; glomeruli (b) Metanephros in group iv.

\begin{tabular}{|c|c|c|c|}
\hline Groups & Comparison & P-value & Significanc \\
\hline \multirow{4}{*}{ I } & II & 0.008 & $<0.05^{*}$ \\
\hline & III & 0 & $<0.05^{\star *}$ \\
\hline & IV & 0 & $<0.05^{\star *}$ \\
\hline & $\mathrm{V}$ & 0 & $<0.05^{* *}$ \\
\hline \multirow{3}{*}{ II } & 1 & 0.008 & $<0.05^{\star}$ \\
\hline & III & 0 & $<0.05^{* *}$ \\
\hline & IV & 0.005 & $<0.05^{*}$ \\
\hline \multirow{3}{*}{ III } & 1 & 0 & $<0.05^{\star \star}$ \\
\hline & II & 0 & $<0.05^{\star *}$ \\
\hline & V & 0.093 & $>0.05$ \\
\hline \multirow{3}{*}{ IV } & 1 & 0 & $<0.05^{\star \star}$ \\
\hline & II & 0.005 & $<0.05^{\star}$ \\
\hline & V & 0.997 & $>0.05$ \\
\hline \multirow{3}{*}{ V } & 1 & 0 & $<0.05^{\star *}$ \\
\hline & III & 0.093 & $>0.05$ \\
\hline & IV & 0.997 & $>0.05$ \\
\hline
\end{tabular}

${ }^{*} \mathrm{p}$-value $<0.05$ siginificant, ${ }^{* *} \mathrm{p}$-value $<0.001$ highly siginificant

Table 2: Proximal tubular diameter in control and experimental groups II, III, IV and $\mathrm{V}$ (metanephros).

\begin{tabular}{|c|c|c|c|}
\hline Groups & Comparison & P-value & Significanc \\
\hline \multirow{3}{*}{ I } & II & 0.48 & $>0.05$ \\
\cline { 2 - 4 } & III & 0.008 & $<0.05^{*}$ \\
\cline { 2 - 4 } & IV & 0.26 & $>0.05$ \\
\hline \multirow{3}{*}{ II } & V & 0.003 & $<0.05^{*}$ \\
\cline { 2 - 4 } & I & 0.48 & $>0.05$ \\
\hline \multirow{3}{*}{ III } & III & 0.34 & $>0.05$ \\
\cline { 2 - 4 } & IV & 0.008 & $>0.05$ \\
\hline \multirow{3}{*}{ IV } & I & 0.34 & $>0.05^{*}$ \\
\cline { 2 - 4 } & II & 0.99 & $>0.05$ \\
\hline \multirow{3}{*}{ V } & I & 0.003 & $>0.05$ \\
\hline & II & 0.99 & $>0.05$ \\
\hline & V & 0.34 & $>0.05$ \\
\hline & I & 0.003 & $<0.05^{*}$ \\
\hline & III & 0.99 & $>0.05$ \\
\hline & IV & 0.34 & $>0.05$ \\
\hline
\end{tabular}

*p-value $<0.05$ siginificant, ${ }^{* *} \mathrm{p}$-value $<0.001$ highly siginificant

Table 3: Proximal luminal diameter in control and experimental groups II, III, IV and $\mathrm{V}$ (metanephros).

\begin{tabular}{|c|c|c|c|}
\hline Groups & Comparison & P-value & Significanc \\
\hline \multirow{4}{*}{1} & II & 0.000 & $<0.05^{* *}$ \\
\hline & III & 0.02 & $<0.05^{*}$ \\
\hline & IV & 0.000 & $<0.05^{* *}$ \\
\hline & V & 0.000 & $<0.05^{\star *}$ \\
\hline \multirow{3}{*}{ II } & 1 & 0.000 & $<0.05^{* *}$ \\
\hline & III & 0.09 & $>0.05$ \\
\hline & IV & 0.000 & $<0.05^{\star *}$ \\
\hline \multirow{3}{*}{ III } & 1 & 0.02 & $<0.05^{*}$ \\
\hline & II & 0.09 & $>0.05$ \\
\hline & V & 0.09 & $>0.05$ \\
\hline \multirow{3}{*}{ IV } & 1 & 0.000 & $<0.05^{\star *}$ \\
\hline & II & 0.000 & $<0.05^{\star *}$ \\
\hline & V & 0.000 & $<0.05^{* *}$ \\
\hline \multirow{3}{*}{ V } & 1 & 0.000 & $<0.05^{\star *}$ \\
\hline & III & 0.09 & $>0.05$ \\
\hline & IV & 0.000 & $<0.05^{\star *}$ \\
\hline
\end{tabular}

${ }^{*} \mathrm{p}$-value $<0.05$ siginificant, ${ }^{* *} \mathrm{p}$-value $<0.001$ highly significant

Table 4: Epithelial height of columnar cells of proximal tubules in control and experimental groups II, III, IV and V (metanephros).

processing and staining was carried out subsequently to observe the changes in the histomorphology of the tissue. The future kidney that is the metanephros was observed for changes and diameter and epithelial height of proximal tubules was measured at $40 \mathrm{X}$ after calibrating ocular micrometer (Figure 1).

\section{Results}

In the control group, the mean tubular (external) and mean luminal (internal) diameters of proximal tubules in the metanephros were 40.53 $\pm 0.08 \mu \mathrm{m}$ and $12.51 \pm 1.00 \mu \mathrm{m}$ respectively. Mean epithelial height of the columnar cells of the proximal tubules, that were PAS positive was $12.44 \pm 0.25 \mu \mathrm{m}$ in the metanephric tissue.

The mean proximal tubular diameter in the metanephric tissue of the experimental group II was $37.07 \pm 0.054 \mu \mathrm{m}$, in group III was 30.30 $\pm 0.041 \mu \mathrm{m}$, in group IV was $33.33 \pm 0.077 \mu \mathrm{m}$ and in group $\mathrm{V}$ was 
Citation: Rehman S, Butt SA, Waseem N, Yousaf M (2015) The Histomorpholigical Changes in the Proximal Tubules of Metanephros of Developing Kidney of Chick Embryo Induced by Electromagnetic Radiations from Conventional and Advanced Mobile. Biol Med (Aligarh) 7: 237 doi: 10.4172/0974-8369.1000237

Page 3 of 3

$32.97 \pm 0.85 \mu \mathrm{m}$.

The mean proximal luminal diameter in metanephric tissue of group II was $11.16 \pm 0.14 \mu \mathrm{m}$, in group III was $9.55 \pm 0.38 \mu \mathrm{m}$, in group IV was $10.82 \pm 0.52 \mu \mathrm{m}$ and in group V was $9.16 \pm 0.31 \mu \mathrm{m}$. In metanephros the mean height of proximal tubular cells in group II was $10.40 \pm 0.12 \mu \mathrm{m}$, in group III was $11.34 \pm 0.46 \mu \mathrm{m}$, in group IV was $7.21 \pm 0.07 \mu \mathrm{m}$ and in group $\mathrm{V}$ was $10.35 \pm 0.14 \mu \mathrm{m}$ (Tables 2- 4).

\section{Discussion}

In metanephric tissue, when group I was compared with the experimental groups, showed that EMR of mobile phone had effects on the histomorphology of developing tissue. Statistically significant results on comparison of group II with group III showed that advanced mobile phone radiations had more effect on tubular diameter. Statistically significant result on comparison of group II with IV showed that the increased exposure from 15 to 30 minutes to conventional mobile phone radiations affected the tubular diameter more. Regarding luminal diameter in metanephros, statistically significant results on comparing group I with group III and group I with group V,showed that advanced mobile phone radiations were affecting the tissue more than conventional mobile phone radiations. Renal tubules showed dilatation, observed by Al-Glaib et al. [3] in mouse kidney induced by GSM mobile phone radiations but Accinni et al. [4] gave an account of collapse of the renal tubules.

In metanephros, the results were statistical significant when group I was compared with all the experimental groups and when group II was compared with IV and group IV with V, for the cells lining the proximal tubules. Here conventional mobile phone radiations seemed to be decreasing the cells' height more than advanced ones that appeared to lead to growth enhancement as per finding of Zareen et al. [5]. The epithelial height was observed to be affected by electromagnetic radiations as it decreased in the germinal epithelial in the rat testis induced by cellular radiation [6] but opppsite was noticed in the thyroid follicular cells which showed an increase in the height of cell lining follicles [7].

The combined use of GSM and WI-FI in our modern cellular phones has effects on the developing tissue. The radiations reduced the size of the tubules and height of the cells which shows the radiations affect growth of developing tissue, moreover the combination of radiations and increased exposure to the combination of both type of radiations affected the histomorphology of tubular and luminal diameters whereas epithelial height seemed to be affected more by GSM radiations that caused them to decrease and combination of GSM and WI-FI appeared to revert the cellular height to increase growth.

\section{Acknowledgment}

To National University Of Science and Technology, Islamabad for funding.

\section{References}

1. Agarwal A, Singh A, Hamada A, Kesari K (2011) Cell Phones and Male Infertility: A Review of Recent Innovations in Technology and Consequences. Int. Braz J Urol 37: 432-454.

2. Hamburger $\mathrm{V}$, Hamilton $\mathrm{HL}$ (1951) A series of normal stages in the development of the chick embryo. J Morphol 88: 49-92.

3. Al-Glaib B, Al-Dardfi M, Al-Tuhami A, Elgenaidi A, Dkhil M (2008) A technical report on the effect of electromagnetic radiation from a mobile phone on mice organs. Libyan J. Med 3: 8-9.

4. Accinni L, De Martino C, Mariutti G (1988) Effects of radiofrequency radiation on rabbit kidney: a morphological and immunological study. Exp Mol Pathol 49: 22-37.

5. Zareen N, Khan MY, Minhas LA (2009) Derrangement of chick embryo retinal differentiation caused by radiofrequency electromagnetics fields. Congenital Anamolies, 49: 15-19.

6. Al-Damegh MA (2012) Rat testicular impairment induced by electromagnetic radiation from a conventional cellular telephone and the protective effects of the antioxidants vitamins C and E. Clinics (Sao Paulo) 67: 785-792.

7. Shaukat F, Qamar K, Butt SA (2011) Effects of mobile phone induced electromagnetic field on height of follicular cells in thyroid gland of mice. Journal of Rawalpindi Medical College 15: 27-29. 